\title{
PANDANGAN IBN QAYYIM AL-JAWZIYYAH TENTANG PERSETUJUAN ANAK GADIS DALAM PERKAWINANNYA
}

\section{A. Hasyim Nawawie*}

\section{Abstrak}

Wanita dewasa yang masih gadis menurut mayoritas imam mazhab tidak mempunyai kebebasan untuk memilih pasangan dan hak itu sepenuhnya menjadi otoritas bapak sebagai wali. Pada hal dengan kedewasaan seorang wanita memungkin ia untuk menyampaikan apa yang ada dalam hati dan pikirannya. Menurut Ibn Qayyim Al-Jawzuyyah, menurut beliau gadis yang sudah dewasa mempunyai hak untuk memilih calon suaminya. Dengan kata lain tidak seorang pun yang bisa memaksanya untuk menikah. Bagian lain yang menjadi dasar perbedaan pendapat para ulama dalam kaitan ini adalah metode para ulama dalam mengis \inbatkan hukum pada kasus ini. Dengan metode is tinbat hukum yang berbeda tersebut berimplikasi kepada penetapan hukum yang berbeda pula walaupun pada dasarnya nash yang digunakan sama. Metode is tinbat hukum yang digunakan para ulama ada dua macam dalam hal ini yaitu mafhum mukhalafah dan mantuq nas\{.

Kata Kunci: Persetujuan anak Gadis, Perkawinan

\section{Pendahuluan}

Perkawinan merupakan transaksi (akad) yang istimewa dalam Islam melebihi transaksi lainnya semisal jual beli. Oleh karenanya ketika akan melakukan perkawinan tersebut perlu pertimbangan yang matang dan pemenuhan terhadap ketentuanketentuan yang mendukung tercapainya tujuan perkawinan. Salah satu ketentuan yang diharapkan dapat membawa kepada

* STAIN Tulungagung 
tercapainya tujuan perkawinan tersebut adalah adanya persetujuan atau kebebasan anak gadis dalam menentukan calon suaminya.

Dengan adanya persetujuan anak gadis tersebut, ternyata di kalangan fuqaha' terjadi perbedaan pendapat. Hal ini diindikasikan dengan terpecah mereka kepada dua kubu. Kubu pertama menyatakan bahwa persetujuan hukumnya hanya sekedar sunat, tanpa ada persetujuan pun, perkawinan tetap sah. Sedangkan kubu lain berpendapat persetujuan adalah sesuatu yang menentukan (wajib). Artinya apabila persetujuan tidak ada, maka perkawinan batal alias tidak sah. Pada golongan pertama termasuk imam Syafi'i yang mana pendapatnya diikuti mayoritas masyarakat Indonesia. Sedangkan di golongan kedua diikuti oleh Ibn Qayyim al-Jawziyyah yang juga merupakan salah satu tokoh besar dalam dunia Islam.

Perbedaan pendapat di antara Ibn Qayyim al-Jawziyyah dengan mayoritas fuqaha' merupakan sebuah fenomena yang menarik untuk dikaji. Hal tersebut memberikan kesempatan kepada penyusun untuk membuka tabir apa sesungguhnya yang menjadikan para ulama tersebut berbeda pendapat. Disamping itu, untuk menyempurnakan penelitian ini penyusun mencoba menemukan relevansi pemikiran Ibn Qayyim al-Jawziyyah tersebut dengan perundang-undang tentang perkawinan yang berlaku di Indonesia.

Persoalan persetujuan anak gadis dalam perkawinan termasuk dalam ranah fiqh, yang mana fiqh itu sendiri bersumber dari nash. Oleh karena itu penyusun dalam mendekati persoalan ini menggunakan pendekatan normatif induktif. Di samping itu, juga menghubungkannya teori al-Maqasid asySyari 'ah atau yang lebih dikenal sebagai memelihara lima unsur pokok dalam syari'at agama hifz ad-Din, hifz al-Nafs, hifz al'Aql, hifz an-Nasl, dan hifz al-Mal). Dengan harapan apa yang menjadi tujuan syari'ah berupa maslahah bisa dimunculkan.

Berdasarkan metode yang digunakan akhirnya bisa dilihat bahwa akar dari perbedaan pendapat diantara Ibn Qayyim al-Jawziyyah dengan mayoritas fuqaha' adalah karena Ibn Qayyim al-Jawziyyah menggunakan mantuq nas (makna eksplisit) yang dikuatkan dengan illat as-suqr dalam istinbat hukumnya. Sementara mayoritas fuqaha' menggunakan mafhum 
mukhalafah (makna implisit) dalam istinbat hukumnya yang dikuatkan dengan memakai 'illat al-bikr. Penelitian yang dilakukan penyusun juga memberikan jawaban bahwa pendapat Ibn Qayyim al-Jawziyyah tersebut sejalan dengan perundangan yang berlaku di Indonesia.

\section{Tinjauan Umum Tentang Persetujuan Anak Gadis Dan Kebebasan Wanita}

\section{Dasar hukum}

Secara umum bisa dikatakan bahwa ketika para ulama membahas tentang persetujuan gadis dalam perkawinan, mereka biasanya menggunakan hadis-hadis sebagai dasar hukum bagi kasus ini. Ulama terpisah menjadi dua pendapat ketika membahas kajian ini. satu pihak menyatakan bahwa persetujuan gadis dalam perkawinan hanya sekedar sunat atau penyempurna, sedangkan di pihak lain berpendapat bahwa persejuan gadis dalam pernikah adalah wajib, artinya tanpa ada persetujuan darinya perkawinan tidak sah.

Berikut ini sejumlah hadis yang dijadikan pegangan bagi pendapat yang menyatakan bahwa persetujuan si gadis hanya sekedar sunnat antara lain:

Hadis dari Ibn 'Abbas, Nabi bersabda:'

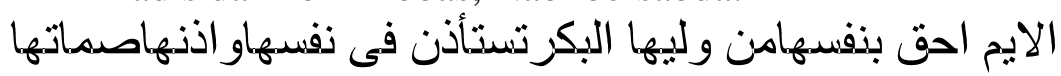

Hadis Ibn 'Abbas tersebut menjelaskan bahwa wanita ada dua golongan. Pertama janda dan kedua gadis. Kekuasaan bapak gadis selaku wali terhadap kedua golongan ini tidak sama. Permulaan hadis tersebut menegaskan bahwa janda lebih berhak terhadap dirinya daripada walinya. Mafhum Mukhalafah-nya adalah bahwa bapak lebih berhak terhadap diri gadisnya. ${ }^{2}$

Riwayat yang menerangkan bahwa gadis diminta persetujuannya, hendaklah diartikan bahwa hukum meminta

${ }^{1}$ Imam an-Nawawi, S\{ah\{ih\{ Muslim bi Syarh\{i an-Nawawi, cet V (beirut: dar al-fikr, t.t.), IX: 202, "Kitab an-Nikah\{", "Bab Isti'z|an fi annikah\{ bi an-Nut\{q wa al-Bikr bi as-Sukut,Sanad hadis ini marfu“ muttas\{il, hadis dari Sa'id bin Mansur dan Qutaibah bin Sa'id diceritakan Sufyan diceritakan Jiyad bin $\mathrm{Sa}^{6} \mathrm{Ad}$

2 Ibrahim Hosen, Fiqh Perbandingan Masalah Perkawinan, cet I (Jakarta: Pustaka Firdaus, 2003), I: 207 
persetujuan itu adalah sunat bagi bapak sekedar membesarkan hati anak gadisnya dan wajib hukumnya bagi selain bapak. ${ }^{3}$

Hadis dari Khansa' binti Khidam: ${ }^{4}$

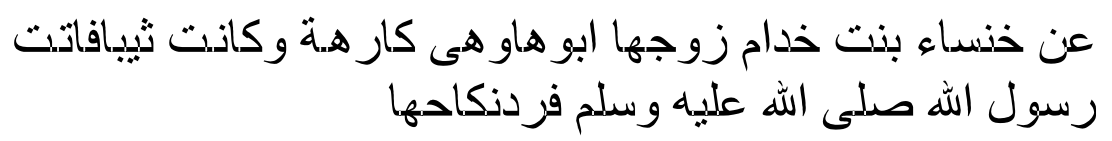

Perkataan perawi hadis yang berupa "sedangkan ia janda" jelas suatu isyarat yang menunjukkan illat atau sebab dari penolakan (tidak diakui) rasul. Hal yang sebaliknya adalah jika ia gadis maka perkawinannya akan diterima Rasul. ${ }^{5}$

Hadis dari Ibn 'Abbas, Nabi bersabda:

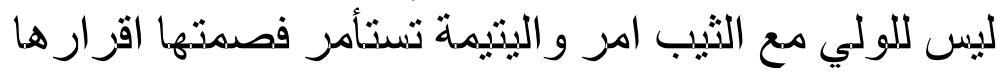

Dalam hadis ini gadis yang tidak berbapak dan sudah dewasa dikatakan yatimah dari segi باعتبرماكان menurut ilmu balaghah, karena istilah yatimah adalah sebenarnya adalah term bagi anak yang tidak berbapak yang belum dewasa menurut arti yang hakiki.

Perkataan تسدتأمر mernjadi qarinah karena orang yang belum dewasa tidak dianggap sah perintahnya dan haruslah kita menunggu sampai ia dewasa. ${ }^{8} \mathrm{Jadi}$, gadis yang tidak berbapak wajib diminta persetujuanya. Ini menunjukkan bahwa gadis yang berbapak tidak perlu bapak meminta persetujuannya. ${ }^{9}$

Adapun hadis yang dijadikan pegangan bagi pendapat yang menyatakan bahwa seorang bapak wajib meminta persetujuan anak gadisnya ketika akan menikahkannya adalah

${ }^{3}$ Ibid.

4 Bukhari, S\{ah\{ih\{ Bukhari, cet. III (Beirut: Dar al-Fikr, 1401/1981), V: 135, "Kitab an-Nikah\{”, "Bab Iz\{a Zawwajahu Ibnatahu wa Hiya Karihah fa Nikahuhu Mardud". Sanad hadis ini marfu 'muttasil, hadis diceritakan oleh Ismail diceritakan Malik dari Abdul ar-Rah\{man.

${ }^{5}$ Ibrahim Hosen, Fiqh Perbandingan, h. 209

${ }^{6}$ Jala $>1$ ad-Din as-Suyuti,Sunan an-Nasa $i$ bi Syarhi al-H \{afiz Jala>1 ad-Din as-Suyuti, , cet I (Beirut: Da>r al-Fikr, 1248/1930), VI: 85, "Kitab anNikah\{", "Bab Isti'zan al-Bikr Fi Nafsiha, sanad hadis ini marfu" muttas\{il, hadis diceritakan oleh Muh\{ammad bin Rafi' diceritakan oleh 'Abdul arRazzaq diceritakan oleh $\mathrm{Mu}^{\prime}$ ammar bin ar-Rasyid dari $\mathrm{S}\{$ alih\{ bin Kaisan

${ }^{7}$ Ibid., h. 209

${ }^{8}$ Ibid.

${ }^{9}$ Ibid. 
sebagai berikut: Hadis dari Abu Hurairah yang diriwayatkan oleh jama'ah: ${ }^{10}$

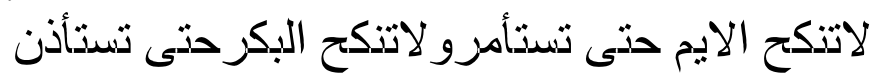

Dalam hadis Abu Hurairah ini, terdapat pengertian yang berupa larangan Rasul untuk menikahkan gadis tanpa seizinnya, sebagaimana beliau menikahkan janda tanpa seizinnya. Secara implisit hadis tersebut menjelaskan sahnya akad nikah tergantung ada atau tidak persetujuan wanita yang akan dinikahkan. Persetujuan tersebut bila dari janda berwujud ucapan sendangkan dari gadis cukup dengan diamnya saja. Hal ini menunjukkan bahwa perbedaan antara gadis dengan janda adalah terletak pada cara penyampaian persetujuan itu sendiri. ${ }^{11}$ Hadis dari Ibn 'Abbas: ${ }^{12}$

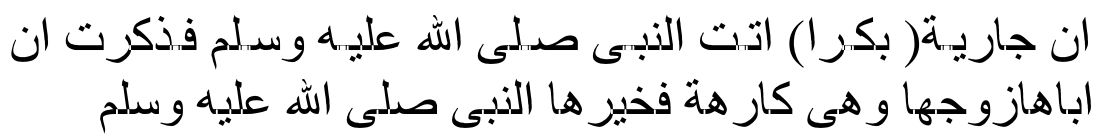

Hadis ini menceritakan suatu kasus pada masa Nabi di mana ketika itu seorang gadis datang menghadap beliau untuk mengadukan bapaknya yang telah menikahkannya tanpa persetujuannya. Terhadap kasus ini Nabi memberikan kepada si gadis hak khiyar (kesempatan untuk memilih) karena perkawinan dilangsungkan tanpa persetujuan si gadis. Hadis ini menunjukkan bahwa seorang bapak tidak sah menikahkan anak gadisnya tanpa persetujuannya.

Wanita yang datang kepada pada hadis ini bukanlah Khansa' binti Khidam wanita yang disebutkan pada hadis sebelumnya yang memang sudah janda. Jadi, ada dua wanita

${ }^{10}$ Imam an-Nawawi, Sahih Muslim bi Syarhi an-Nawawi, cet V (Beirut: Da>r al-Fikr, t.t.), IX: 202, "Kitab an-Nikah", "Bab Isti'z|an fi annikah bi an-Nutq wa al-Bikr bi as-Sukut,Sanad hadis ini marfu' muttasil, hadis diceritakan 'Ubaidillah bin 'Umar bin Maisarah al-Qawari<ri< diceritakan Khalid bin al-Haris diceritakan Hisyam bin Yah\{ya.

${ }^{11}$ Ibrahim Hosen, Fiqh Perbandingan Masalah Perkawinan, cet I (Jakarta: Pustaka Firdaus, 2003), h. 211

${ }^{12}$ Abu Daud, Sunan Abi Daud, cet. I (Beirut: Dar al-Fikr,t.t.), II: 232, hadis nomor 2096,"Kitab an-Ni<kah", "Bab al-Bikr Yuzawwijuha Abuha wa la Yasta'miruha." sanad hadis ini marfu' muttasil, hadis diceritakan oleh Usman bin Abi Syaibah diceritakan oleh Husain bin Muhammad diceritakan oleh Jari<r bin $\mathrm{H}\{$ azi $<\mathrm{m}$.

${ }^{13}$ Ibrahim Hosen, Fiqh Perbandingan., h. 212 
dengan status yang berbeda, yang pertama janda dan yang kedua masih gadis. Akan tetapi Nabi memberikan perlakuan yang sama terhadap kedua wanita itu. ${ }^{14}$

Hadis dari Siti 'Aisyah: ${ }^{15}$

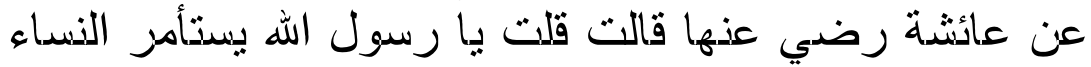

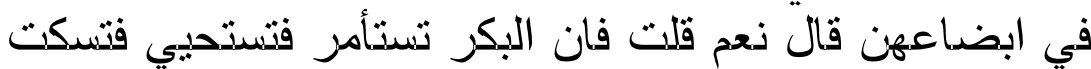

Hadis dari Siti 'A<isyah: ${ }^{16}$

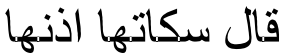

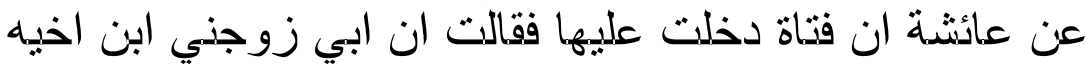
ليزفع بي خسيسته وانا كارهة قالت اجلسي حتى باتي التي النبي زئي صلى اللهم عليه وسلم فجاء رسول الله صلى الله فلهم عليه وسلم

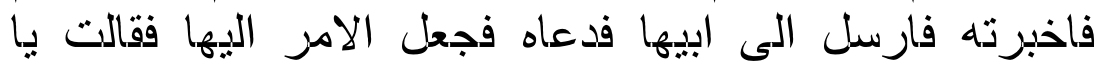

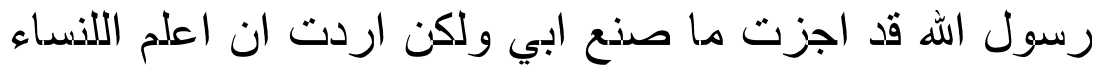
من الامر شيء

Perkataan fatatun dalam hadis Siti A'isyah ini, diasumsikan sebagai wanita yang masih gadis. Demikian juga perkataan wanita tersebut di depan Rasul yang berupa "tetapi aku hanya ingin memberitahukan kepada para wanita bahwa bapak tidak mempunyai suatu urusan (hak) apa pun " jelas menunjukkan bahwa bapak tidak mempunyai hak ijbar terhadap anak gadisnya, karena perkataan an-nisa' (para wanita) mencakup seorang wanita yang masih gadis. ${ }^{17}$

\section{Pandangan Ulama-Ulama Fiqh}

${ }^{14}$ Ibn Qayyim al-Jawziyyah, Zaadul Ma'ad (Bekal Menuju Akhirat), alih bahasa Kathur Suhardi, cet V (Jakarta: Pustaka Azzam, 2004), V: 386

15 Bukhari<, Sahi<h Bukhari<, cet. III (Beirut: Da>r al-Fikr, 1401/1981), V: 135, "Kitab an-Nika\{", "Ba>b la> Yaju>zu Nika>h\{ alMukrah". Sanad hadis ini marfu>" muttas $\{$ il, hadis diceritakan oleh Muh\{ammad bin Yusuf dari Sufyan bin Sa'id dari 'Abdul al-Malik bin Juraij

${ }^{16}$ Jalal ad-Din as-Suyuti,Sunan an-Nasa> $i$ bi Syarhi al-Hafiz Jalal ad-Din as-Suyuti, , cet I (Beirut: dar al-fikr, 1248/1930), VI: 86-87, "Kitab an-Nikah\{", "Bab al-Bikr Yuzawwijuha Abu>ha wa Hiya Karihah, sanad hadis ini marfu' muttasil, hadis diceritakan oleh Ziyad bin Ayyub diceritakan 'Ali< bin Gurab diceritakan oleh Kahmas bin al-Hasan

${ }^{17}$ Ibrahim Hosen, Fiqh Perbandingan., h. 213 
Ada pemetaan menarik yang dibuat oleh Ibn Rusyd tentang perbedaan pendapat ulama tentang kebebasan wanita dalam memilih pasangan yang dapat dirinci sebagai berikut: ${ }^{18}$

a. Para ulama sepakat bahwa untuk wanita janda diwajibkan ada persetujuannya.

b. Janda yang belum balig, menurut imam Ma>lik dan imam Ha $>$ nafi<, wali boleh memaksanya untuk menikah, sedangkan menurut imam Sya>fi'i< wali tidak boleh menikahkannya tanpa persetujuannya.

c. Mengenai gadis kecil para imam mazhab sepakat bahwa ia boleh dinikahkan tanpa persetujuannya, akan tetapi mereka berbeda pendapat tentang siapa yang boleh menikahkannya tanpa persetujuannya. Menurut Sya>fi'i yang boleh menikahkannya tanpa persetujuannya adalah bapak dan kakeknya, sedangkan imam Ma>lik mengatakan yang boleh hanya bapaknya saja atau orang yang mendapat penyerahan dari bapak untuk melakukan akad itu jika calon suami telah ditentukan bapak, dan pendapat imam $\mathrm{Ha}>$ nafi $<$ adalah setiap orang yang mempunyai hak wali terhadap si gadis boleh menikahkanya walaupun tanpa persetujuannya, akan tetapi setelah dewasa si anak gadis mempunyai hak khiya>r (memilih).

d. Ulama berbeda pendapat tentang persetujuan sendiri itu jika wanitanya gadis dewasa. Imam Ma>lik dan imam asy-Syafi'i berpendapat persetujuan hanya sekedar sunat, bahkan bapak sebagai wali bisa memaksa anak gadis untuk menikah dengan laki-laki pilihannya, sedangkan menurut imam Hanafi harus ada persetujuan dari si gadis.

\section{Analisis pandangan Ibn Qayyim al-Jawziyyah}

Secara ideal-normatif, Islam sesungguhnya tidak membedakan antara pria dengan wanita, atau dengan kata lain Islam menolak segala bentuk diskriminasi yang berbau gender. Islam sebagai pembawa keselamatan dan kerahmatan bagi

${ }^{18}$ Ibn Rusyd, Bida>yah al-Mujtahid Wa Niha>yah Al-Muqtas\{id (Analisa Fiqh Para Mujtahid), alih bahasa Imam Ghazali Said dan Achmad Zaidun, cet II (Jakarta: Pustaka Amani, 2002), II: 398-404 
seluruh alam (rah\{matan lil 'alamin) menempatkan drajat dan posisi wanita pada kedudukan yang mulia. ${ }^{19}$

Wanita sebagai kenyataan sosial masyarakat Arab pada masa Nabi, menjadi salah concren yang ingin dibela al-Qur'an, disamping kelompok budak, kaum fakir miskin, anak-anak miskin, dan sederet kaum lemah lainnya. Bahkan al-Qur'an secara khusus mendokumentasikannya dalam satu surat khusus yang bernama an-Nisa'. ${ }^{20}$

Sejumlah indikasi bisa diketengahkan untuk melihat pembelaan al-Qur'an terhadap wanita di antaranya: ${ }^{21}$ pertama, ayat al-Qur'an yang secara tegas menyebutkan bahwa wanita dan laki-laki adalah sejajar seperti: ${ }^{22}$

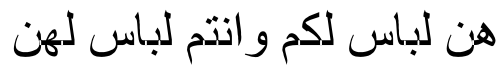

Kedua, sejumlah ayat yang secara tegas merombak kebiasaan Arab pra-Islam. Di antara indikasi tersebut adalah larangan mengubur hidup-hidup anak perempuan yang baru lahir, karena menurut masyarakat Arab pra-Islam anak perempuan itu akan mencemarkan nama baik keluarga. Prilaku ini jelas diprotes al-Qur'an. ${ }^{23}$

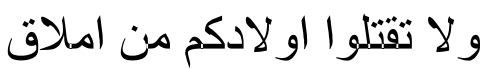

Ketiga, larangan al-Qur'an mewariskan wanita, bahkan lebih dari itu Islam juga memberikan hak waris kepada wanita. ${ }^{24}$
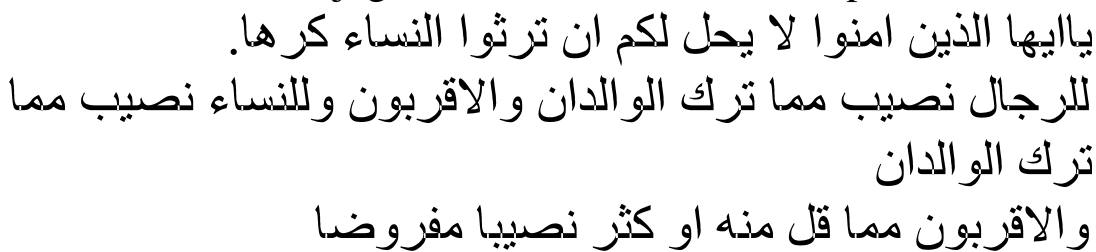

Hal ini merupakan bukti nyata bahwa al-Qur'an berusaha membebaskan wanita dari budaya yang mendiskriminasikannya.

19 Masdar F. Mas‘udi, "Meletakkan Maslahat Sebagai Kerangka Acuan Syari ‘ah,'Ulumul Qur 'an, Vol. 4: 3, (1995), h, 94

${ }^{20}$ Nurjanah Ismail, Perempuan dalam Pasungan: Bias Laki-Laki dalam Penafsiran, cet. I (Yogyakarta: LKiS, 2003), h. v

21 Khoiruddin Nasution, Fazlurrahman Tentang Wanita, cet. I (Yogyakarta: Tazzafa Academia, 2002), h. 3-4

${ }^{22}$ Al-Baqarah (2) : 187

${ }^{23} \mathrm{Al}-\mathrm{An}$ 'am (6) : 151

${ }^{24}$ An-Nisa' (4) : 19 dan 7 
Karena harus diakui ketika al-Qur'an diturunkan rezim patriarki Arab masih sangat kental. ${ }^{25}$

Pembelaan al-Qur'an terhadap wanita tersebut menjadi salah satu misi pokok yang diperjuangkan oleh Nabi Muhammad dengan agama Islam yang dibawanya. Akan tetapi bukti sejarah berkata lain, hampir sepanjang sejarah muslim, kaum wanita ditempatkan pada posisi inferior sementara lakilaki berada pada posisi superior. Padahal al-Qur'an menempatkan posisi wanita sejajar dengan laki-laki. ${ }^{26}$

Munculnya praktek yang inferior terhadap wanita dalam sejarah muslim, bukan tanpa alasan. Hal ini disebabkan antara lain adanya sejumlah nash terkesan mengisyatkan adanya kemungkinan itu ${ }^{27}$. Di antaranya adalah: ${ }^{28}$

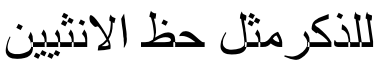

Faktor lain yang menyebabkan munculnya praktek yang inferior terhadap wanita adalah pengaruh metode studi nash yang dipakai para ulama. Bisa dikatakan bahwa umumnya ulama tradisional, menggunakan pendekatan parsial dalam mengkaji al-Qur'an dan sunnah Nabi, Yaitu menyelesaikan satu masalah dengan cara memahami salah satu atau beberapa nash secara berdiri sendiri, tanpa menghubungkan dengannya dengan nash lain yang relevan. ${ }^{29}$

Salah satu fakta yang berbicara tentang praktek yang inferior terhadap wanita adalah hak kebebasannya dalam menentukan calon suami. Wanita dewasa yang masih gadis menurut mayoritas imam mazhab tidak mempunyai kebebasan untuk memilih pasangan dan hak itu sepenuhnya menjadi otoritas bapak sebagai wali. Pada hal dengan kedewasaan seorang wanita memungkin ia untuk menyampaikan apa yang ada dalam hati dan pikirannya. Dan dengan kedewasaan itu pula

\footnotetext{
${ }^{25}$ ibid.

${ }^{26}$ Khoiruddin Nasution, Fazlurrahman, h. 2

${ }^{27}$ Ibid., h. 5

28 An-Nisa' (4) : 11

${ }^{29}$ Khoiruddin Nasution, Fazlurrahman Tentang, h. 9
} 
seorang wanita memiliki kapasitas untuk melaksanakan apa yang ada dalam pikirannya. ${ }^{30}$

Pendapat mayoritas imam mazhab tersebut bila diteliti lebih jauh masih merupakan peninggalan tradisi arab pra Islam. Sejarah menuliskan bahwa sebelum kedatangan Islam, seorang bapak memiliki hak utnuk memilihkan suami bagi putrinya dan putrinya tidak berhak untuk menentang. Bahkan tradisi Arab pra Islam yang tidak menghargai hak wanita adalah tidak jarang para bapak saling menukar putri mereka untuk menikah satu sama lain. Ini dikenal dengan nikah syigar dalam Islam, akan tetapi kemudian nikah dengan jenis seperti ini dibatalkan sekaligus diharamkan oleh Islam. ${ }^{31}$

Sebelum memberikan penilaian lebih jauh dalam persoalan ini, ada baiknya penulis menguraikan bagian-bagian yang menjadi ruang perdebatan para ulama dalam membahas kajian ini, agar memperoleh pemahaman yang konprehensif tentang persoalan ini. Salah satu Bagian yang menjadi perdebatan berkaitan dengan hak wanita dalam memilih pasangan adalah illat yang dijadikan sebagai dasar argumen untuk menentukan ada tidaknya hak kebebasan itu sendiri. Sebagian ulama dalam kaitan ini menjadikan kegadisan (al-bikr) sebagai illat dalam penentuan hukumnya, sementara ulama yang lain dengan menggunakan illat masa kecil (as $\{-s\{u g\{r)$, bahkan ada ulama yang menjadikan illat bagi kasus ini dengan menggabungkan kedua 'illat tersebut. ${ }^{32}$

Dalam kasus ini, ada kritikan yang disampaikan oleh Ibn Taimiyah, yang menyatakan bahwa sesungguhnya menjadikan kegadisan sebagai alasan yang mewajibkan untuk membatasi hak wanita adalah bertentangan dengan prinsip Islam, dan menjadikan hal itu sebagai illat untuk membatasi atau mengahalangi kaum wanita merupakan pembuatan illat dengan

${ }^{30}$ Husein Muhammad, Fiqh Perempuan Refleksi Kiyai Atas Wacana Agama Dan Gender, (Yogykarta: LKiS, 2001), h. 83-84

${ }^{31}$ S. M. Khamenei, Risalah Hak Asasi Wanita: Studi Komparatif antara Pandangan Islam Dan Deklarasi Universal HAM, alih bahasa Quito R. Motinggo, cet. I (Jakarta: al-Huda, 2004), h. 81

Ibn Rusyd, Bidayah al-Mujtahid Wa Nihayah Al-Muqtas id (Analisa Fiqh Para Mujtahid), alih bahasa Imam Ghazali Said dan Achmad Zaidun, cet. II (Jakarta: Pustaka Amani, 2002), II: 403-404 
sesuatu sifat yang tidak ada pengaruhnya dalam syara' ${ }^{33}$ Beliau menambahkan bahwa illat yan benar untuk kasus ini adalah masih kecil

Ibn Qayyim al-Jawziyyah sependapat dengan gurunya Ibn Taimiyyah bahwa illat yang dijadikan sebagai pijakan hukum ada tidaknya hak tersebut adalah illat usia kecil, sehingga menurut beliau gadis yang sudah dewasa mempunyai hak untuk memilih calon suaminya. Dengan kata lain tidak seorang pun yang bisa memaksanya untuk menikah.

Bagian lain yang menjadi dasar perbedaan pendapat para ulama dalam kaitan ini adalah metode para ulama dalam mengis\tinbatkan hukum pada kasus ini. Dengan metode is \inbat hukum yang berbeda tersebut berimplikasi kepada penetapan hukum yang berbeda pula walaupun pada dasarnya nash yang digunakan sama. Metode is tinbat hukum yang digunakan para ulama ada dua macam dalam hal ini yaitu mafhum mukhalafah dan mantuq nasi.

Mafhum mukhalafah sebagai pisau analisis digunakan oleh imam Syafi'i, Maliki dan $\mathrm{H}$ \{anbali terhadap kasus ini, membawa mereka pada pendapat bahwa persetujuan anak gadis hanya sekedar sunat dengan berdasarkan hadis ${ }^{34}$

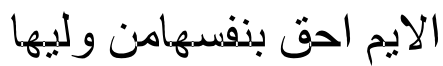

Jika janda lebih berhak terhadap dirinya dari pada walinya, maka mafhum mukhalafahnya adalah wali lebih berhak terhadap diri anak gadisnya, sehingga kemudian mereka berpendapat meminta persetujuan seorang gadis tidak diperlukan lagi.

Dengan hadis yang sama pula ulama yang berpegang pada mantuq nas \{ diwakili oleh imam Hanafi dan Ibn Qayyim al-Jawziyyah, yang menyatakan bahwa persetujuan anak gadis adalah wajib.

${ }^{33}$ Dikutip oleh Yusuf Qardhawi, Fatwa-Fatwa Kontemporer, alih bahasa As‘ad Yasin, cet. II (Jakarta: Gema Insani Press, 1996), II: 471

${ }^{34}$ Imam an-Nawawi<, Sahi<h Muslim bi Syarhi an-Nawawi<, cet V (beirut: dar al-fikr, t.t.), IX: 202, "Kitab an-Nikah", "Bab Isti'z|an fi annikah\{ bi an-Nutq wa al-Bikr bi as-Sukut". Sanad hadis ini marfu“ muttasil, hadis dari $\mathrm{Sa}^{\circ} \mathrm{i}<\mathrm{d}$ bin Mansur dan Qutaibah bin $\mathrm{Sa}{ }^{\prime} \mathrm{i}<\mathrm{d}$ diceritakan Sufyan diceritakan Jiyad bin sa'Ad. 
Ibn Qayyim lebih lanjut mengkritik golongan yang menggunakan mafhum mukhalafah terhadap kasus ini dengan mengatakan bahwa pemahaman yang muncul dari mantuq nas \{ semestinya didahulukan daripada pemahaman yang menggunakan mafhum mukhalafah. Sebab penetapan hukum suatu kasus tertentu belum tentu menetapkan hukum sebaliknya untuk kasus lainnya. Adalah sesuatu yang mungkin kasus lain mempunyai dasar hukum sendiri. ${ }^{35}$

Perbedaan pendapat berkenaan dengan persoalan persetujuan gadis dalam perkawinan, Ibn Qayyim al-Jawziyyah lebih lanjut memberikan analogi bahwa seorang bapak tidak memiliki hak tasarruf terhadap harta milik anak gadisnya yang rasyidah tanpa persetujuannya, apalagi terhadap bud\{u nya (kehormatannya) yang merupakan hartanya yang paling berharga. Lalu, bagaimana mungkin seorang bapak dibolehkan mentasarrufkan harta yang paling berharga tersebut sementara si gadis tidak setuju.

Pada akhirnya persolan pada kebebasan dan persetujuan wanita dalam memilih calon suami, bermuara pada apakah perlu (wajib) atau tidak (sunnah). Ibn Qayyim al-Jawziyyah sebagai salah satu ulama besar dalam lingkungan mazhab $\mathrm{H}\{$ anbali, dalam menyikapi persoalan ini lebih sepakat dengan pandangan Abu Hanifah. ${ }^{36}$ Beliau berpendapat dalam hal ini sebagai sesuatu yang diperlukan (wajib). Dengan pertimbangan

${ }^{35}$ Dikutip oleh Khoiruddin Nasution, Islam: Tentang Relasi Suami Dan Istri (Hukum Perkawinan I), cet I (Yogyakarta: Academia + Tazzafa, 2004), h. 92

${ }^{36}$ Barangkali inilah bukti konkrit sekaligus implikasi dari perkataan beliau. Ibn Qayyim pernah berkata bahwa sepantasnyalah seorang mufti tidak memberikan fatwa kepada orang yang meminta fatwa kepadanya, sesuai dengan pendapat mazhab yang diikutinya. Sementara dalam permasalahan tersebut, ia mengetahui bahwa pendapat dari mazhab lain lebih unggul dibandingkan pendapat mazhabnya atau ia mengetahui sandaran dalil yang dimilikinya lebih shahih. Dikutip oleh Yusuf al-Qaradhawi, Bagaimana Berinteraksi Dengan Peninggalan Ulama Salaf, alih bahasa Ahrul Tsani Fathurrahman dan Muhtadi Abdul Mun'im, cet I (Jakarta: Pustaka alKautsar, 2003), h. 148 
kemaslahatan gadis yang bersangkutan, maka hal ini diserahkan sepenuhnya kepada si gadis dan bukan kepada wali. ${ }^{37}$

Pendapat yang mendukung persetujuan dan kebebasan wanita dalam konteks ke Indonesiaan, Khoruddin Nasution, dalam tulisannya yang dimuat dalam jurnal asy-Syir'ah menjelaskan bahwa tidak ada paksaan dalam memilih pasangan bagi wanita, berdasarkan sejumlah hadis yang digunakan para fuqaha' untuk memecahkan persoalan ada tidak persetujuan dan kebebasan wanita dalam menentukan pasangan, pada prinsipnya hadis-hadis tersebut menekankan pentingnya persetujuan wanita yang bersangkutan. Sebaliknya, dasar yang digunakan fuqaha' yang berpendapat bahwa persetujuan gadis tidak diperlukan dan tidak adanya kebebasan wanita dalam menentukan pasangan adalah lemah, sebab hanya menggunakan mafhum mukhalafah dari nash yang menyebut bahwa janda lebih berhak terhadap dirinya. Padahal secara tekstual (eksplisit) ada nash yang menyebutkan harus ada persetujuan dari wanita yang akan nikah. Beliau menambahkan bahwa penekanan hadis-hadis yang mengharuskan adanya persetujuan wanita yang akan nikah terdistorsi (sengaja atau tidak), untuk mendukung praktek dan pemahaman yang sangat patriarkal yang sudah mapan oleh para fuqaha'. Sebab para fuqaha' itu tinggal dan hidup dalam masyarakat yang patriarkal tersebut. ${ }^{38}$

Khoiruddin nasution dalam mendukung pernyataan di atas, menawarkan satu teori yang bisa dijadikan parameter untuk mengukur ada tidaknya hak kebebasan seorang wanita dalam menentukan pasangan yaitu menghubungkan nash yang berbicara tentang kebebasan dan pemaksaan wanita dalam perkawinan dengan nash yang berbicara dengan perkawinan itu sendiri (paling tidak dengan status akad nikah dan tujuan perkawinan) $)^{39}$

Dalam kaitan ini lebih lanjut, beliau menguraikan bahwa tujuan perkawinan ada tiga macam yang diisyaratkan oleh al-

${ }^{37}$ Ibn Qoyyim al-Jawziyyah, Zad al-Ma'ad (Mesir: Mustafa alBabi< al-Halabi< wa Awladih, 1390/1970), IV: 3

${ }^{38}$ Khoruddin Nasution, ”Mensikapi Kitab-Kitab Fikih Konvensional dalam Menjamin Hak Wanita dalam Menentukan Pasangan", asy-Syir 'ah, No. 8, (2001), h. 140-141

${ }^{39}$ Ibid. 146 
Qur'an, yakni pertama, untuk mengembang biakkan umat manusia (reproduksi) di bumi, sesuai dengan firman Allah: ${ }^{40}$

فاطر السـ موات و الارض جع.ل لك.م م.ن انفس.كم ازواج.ا وم.ن

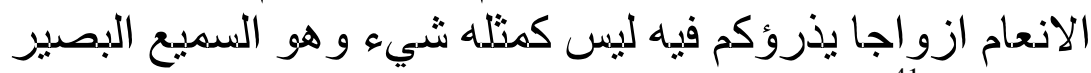
Kedua, pemenuhan kebutuhan seksual, firman Allah:

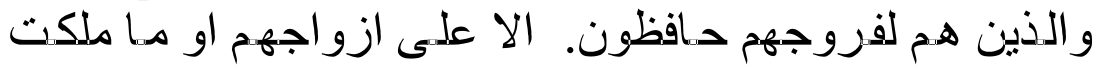

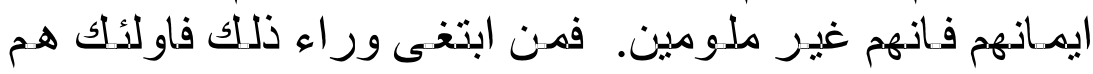
العجادون

Ketiga untuk memperoleh ketenangan (saki<nah), cinta (mawaddah dan kasih sayang (rah\{mah). Dalam firman Allah: ${ }^{42}$

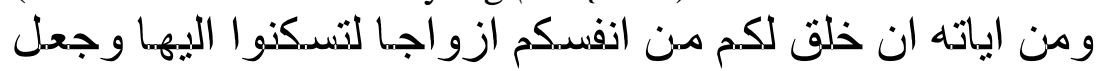

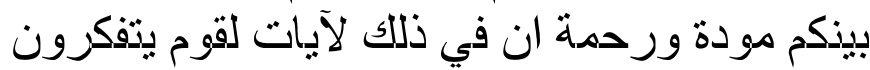

Berdasarkan status dan tujuan perkawinan tersebut lanjut beliau, dapat ditulis minimal dua catatan sebagai berikut. Pertama, perkawinan dalam Islam adalah transaksi yang mulia, melebihi transaksi pada umumnya. Padahal untuk absahnya suatu transaksi (akad) biasa ada keharusan bahwa orang-orang yang mengadakan taransaksi adalah orang-orang yang mukallaf, dengan syarat (1) si mukallaf mempunyai akal fikiran yang berfungsi dengan baik ('aqil), (2) transaksi dilakukan atas kehendak sendiri (tidak dipaksa), sesuai dengan an-Nisa>' (4) : $29,{ }^{43}$ (3) transaksi dilakukan oleh orang yang dewasa. Bisa dianalogikan bahwa untuk sahnya transaksi biasa saja harus dilakukan oleh pihak-pihak yang memenuhi syarat-syarat tersebut, bagaimana mungkin akad nikah, satu transaksi yang melebihi transaksi yang biasa dapat dilakukan dengan paksa (tanpa persetujuan si gadis) dapat dilakukan. Kedua, perkawinan dalam Islam mempunyai tujuan yang sangat mulia dan melahirkan akibat-akibat hukum yang cukup luas. Sebab akad nikah merupakan langkah awal untuk menentukan nasib para pasangan (hidup sebagai suami istiri) selama hidup di dunia. Oleh karena itu, semakin jelas bahwa mestinya akad nikah

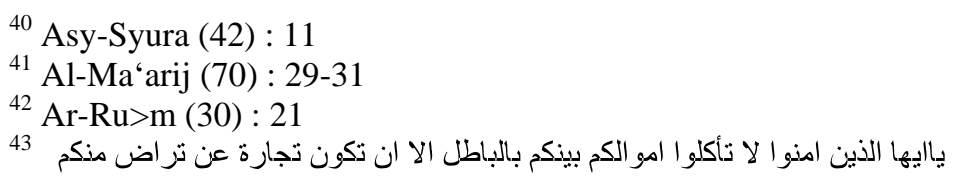


dillakukan pihak-pihak dengan penuh kesadaran dan pertimbangan matang. Tuntunan ini semakin menunjukkan, bahwa keputusan mempelai sebagai pihak-pihak yang merasakannya akibat kelak harus benar-benar mendapatkan perhatian. $^{44}$

Perkawinan berkaitan langsung dengan perasaan wanita, dialah nanti yang akan merasakan manis indah maupun pahit getirnya perkawinan. Oleh karena itu persetujuan dan kebebasannya dalam menentukan calon pendampingnya adalah sesuatu yang menentukan dalam perkawinan. ${ }^{45}$

Islam mengariskan salah satu misi utamanya adalah memperjuangkan hak-hak wanita, maka pandangan yang relevan dalam persoalan ini adalah memberikan hak kepada wanita untuk memilih pasangan mereka. Ini akan menunjukkan kemerdekaan pribadi mereka yang "direnggut" secara sadar atau tidak oleh tradisi yang mengelilinginya. ${ }^{46}$

Berdasarkan hak-hak keIslamannya, seorang gadis dewasa dapat menolak siapa saja yang ia anggap tidak memenuhi syarat sebagai suaminya. Tidak yang dapat memaksakan perkawinan kepadanya. Maka jika dikatakan bahwa apabila ia tidak setuju dengan pernikan yang disodorkan kepadanya, maka perkawinan itu tidak sah. ${ }^{47}$

Bila diteliti lebih jauh akan kelihatan bahwa Ibn Qayyim al-Jawziyyah masih mengakui praktek ijbar terhadap gadis yang belum dewasa. Hal ini diindikasikan dengan ketika 'illat dewasa (balig) sebagai illat yang menentukan ada tidaknya kebebasan wanita dalam menentukan pasangan.

Balig seperti dituliskan dalam Esiklopedia Islam di Indonesia bagi wanita adalah ketika wanita mendapat haid, atau dalam fiqh disebutkan 7 sampai 9 tahun. Dan mayoritas ulama menetapkan batas usia paling akhir adalah 15 tahun, baik untuk pria maupun wanita. ${ }^{48}$

${ }^{44}$ Khoruddin Nasution, "Mensikapi Kitab-Kitab Fikih, h. 146

45 Mohammmad Fauzil Adhim, Kupinang Engkau Dengan

Hamdallah, cet. VII (Yogyakarta: Mitra Pustaka, 1999), h. 93

${ }^{46}$ S. M. Khamenei, Risalah Hak Asasi, h. 80

${ }^{47}$ Ibid.

${ }^{48}$ Departemen Agama R.I, Ensiklopedia Islam di Indonesia (Jakarta: CV. Anda Utama,1993), I: 183 
Ibn Qayyim al-Jawziyyah, dengan kata lain masih membolehka adanya praktek perkawinan dibawah umur. Padahal kematangan umur dari pasangan sangat diperlukan untuk menjaga keutuhan sebuah rumah tangga.

Berkaitan dengan perkawinan gadis dibawah umur ada pendapat menarik dari Ibn Syibrimah yang dikutip oleh Wahbah az-Zuhaili<, beliau mengatakan bahwa mengawinkan gadis di bawah umur tidak sah, demi kemaslahatan anak gadis yang bersangkutan, juga keluarga. Pendapat ini memberikan tuntutan rasional karena rumah tangga itu yang akan menjalani adalah anak perempuannya maka seorang bapak harus memberikan kesempatan anak gadisnya untuk tumbuh dan berkembang menjadi orang dewasa, yang dapat memilih jalan hidupnya serta menentukan jodohnya. Perkawinan hendaknya dilangsungkan setelah masing-masing mencapai taraf kematangan, baik secara fisik-biologis maupun mental-psikogis. ${ }^{49}$

\section{Relevansinya Dengan Konteks Sekarang}

Ibn Qayyim meyakini bahwa maksud ditaklifkannya hukum adalah untuk mewujudkan kemaslahatan dan menghindarkan kemafsadatan bagi manusia. Oleh karena itu, implemenatasi hukum berdasarkan pada maslahat. Hukum berubah karena pertimbangan maslahat. ${ }^{50}$

perubahan dan perkembangan pemikiran hukum Islam yang berpijak pada kemaslahatan akan berubah sesuai dengan waktu dan ruang bukan saja dibenarkan, tetapi merupakan suatu kebutuhan, khususnya bagi umat Islam yang mempunyai kondisi dan budaya yang berbeda dengan Timur Tengah, seperti Indonsia. Hal ini didasarkan pada pertimbangan: pertama, banyak ketentuan-ketentuan hukum Islam yang berlaku di Indonesia merupakan produk ijtihad yang didasarkan pada kondisi dan kultur Timur Tengah. Padahal, apa yang cocok dan baik bagi umat Islam di Timur Tengah, belum tentu baik dan cocok bagi umat Islam di Indonesia. Kedua, kompleksitas

49 K. M. Ikhsanuddin dkk. (ed.), Panduan Pengajaran Fiqh Perempuan di Pesantren (Yogykarta: Yaysan Kesejahteraan Fatayat, t.t.), h. 119

${ }^{50}$ Ibid., h. 111 
masalah yang dihadapi umat Islam dewasa ini terus berkembang dan semakin beragam. ${ }^{51}$

Pendapat Ibn Qayyim al-Jawziyyah yang mewajibkan adanya persetujuan anak gadis sesungguhnya sesuai dengan perundang-undangan yang berlaku di indonesia. Dalam undangundang perkawinan no. 1/1974 (ps. 6 ayat (1) jo. ps. 16 ayat $(1)^{52}$ KHI menetapkan bahwa salah satu syarat perkawinan adalah persetujuan calon mempelai.

Manfaat adanya persetujuan adalah agar masing-masing calon suami istri, memasuki gerbang perkawinan dan berumah tangga, benar-benar dapat dengan senang hati membagi tugas dan hak kewajibannya secara proporsional. Dengan demikian tujuan dari perkawinan itu dapat tercapai ${ }^{53}$

Bisa dilihat bahwa apa yang menjadi pendapat dari Ibn Qayyim sejalan dengan perundang-undang di Indonesia, bahkan boleh dikatakan bahwa maslahat yang dicita-citakan oleh beliau lebih disempurnakan lagi oleh perundang-undangan di Indonesia. Hal ini dibuktikan dengan adanya perundangundangan yang mengatur tentang batasan usia pria maupun wanita yang boleh untuk menikah ${ }^{54}$, dalam perundang-undangan itu tersebut secara jelas disebutkan bahwa batas usia untuk pria 19 tahun sedangkan untuk wanita 16 tahun.

${ }^{51}$ Abdul Halim, "Ijtihad Kontemporer: Kajian Terhadap Beberapa Aspek Hukum Keluarga Islam Indonesia," dalam Ainurrofiq (ed.), Mazhab Jogja: Menggagas Paradigam Ushul Fiqh Kontemporer, cet. I (Yogyakarta: Fakults Syari'ah UIN Sunan Kalijaga + ar-Ruzz Press, 2002), h. 231 mempelai",

52 "perkawinan harus didasarkan atas persetujuan kedua calon

53 Ahmad Rofiq, Hukum Islam di Indonesia, cet. IV (Jakarta: PT. Raja Grafindo Persada, 2000), h. 73-74

${ }^{54}$ Undang-undang no.1/1974 tentang perkawinan, pasal 7 ayat (1) disebutkan "perkawinan hanya diizinkan jika pihak pria sudah mencapai umur 19 (sembilan belas) tahun dan pihak wanita sudah mencapai umur 16 (enam belas) tahun".jo. KHI buku I tentang perkawinan pasal 15 ayat (1) disebutkan "untuk kemaslahatan keluarga dan rumah tangga perkawinan hanya boleh dilakukan calon mempelai yang telah mencapai umur yang telah ditetapkan dalam pasal 7 undang-undang no. 1 tahun 1974 yakni calon suami sekurang-kurangnya berumur 19 tahun dan calon istri sekurang-kurangnya berumur 16 tahun. 
Sehubungan dengan hal tersebut, maka calon suami istri yang telah matang jiwanya agar keduanya dapat mewujudkan tujuan perkawinan secara baik dan harmonis, dan diharapkan tidak berakhir dengan perceraian. Kematangan usia diperlukan, karena berdasarkan pengamatan dan analisis berbagai pihak terhadap kasus-kasus tidak harmonis dan bubarnya sebuah rumah tangga, seringkali disebabkan oleh ketidak matangan usia dan ketidakstabilan integritas pribadi, sehingga sangat berpengaruh di dalam menyelesaikan problem yang muncul dalam bahtera rumah tangga. ${ }^{5}$

Maka jelaslah bahwa dari perspektif maqa>sid asysyari<'ah, konsep maslahah sangat relevan dengan dimensi pluralitas dan dinamika kehidupan manusia. Sebab dengan konsep maslahah, bukan hanya konsep sisi perubahan dan perubahan perkembangan zaman saja yang bisa dianulir, melainkan aspek lokalitas dan dan pluralitas juga tidak terabaikan, sehingga hukum Islam tidak akan kaku, sesuai dengan arahan syari'ah.

Maslahah secara praktis berbeda pada setiap zaman, maka fiqh sebagai produk dari fuqaha' harus disesuaikan dengan konteks sosial dimana fiqh itu diterapkan, namun tentunya tidak bertentangan dengan tujuan syari'ah itu sendiri. ${ }^{56}$

Dengan konsep maslahah sebagai faktor perubahan hukum menjadikan hukum bersifat fleksibel dan dapat beradaptasi dengan perubahan sosial. ${ }^{57}$

Maslahah sebagai faktor perubahan hukum bukanlah sesuatu yang baru di dunia Islam. Teori ini dimunculkan oleh Ibn Qayyim al-Jawziyyah sekitar tujuh abad yang lalu.

${ }^{55}$ Abdul Halim, "Ijtihad Kontemporer", h. 238

${ }^{56}$ M. Hasby asy-Syiddiqi, Filsafat Hukum Islam, cet. V (Jakarta: Bulan Bintang, 1993), h. 337

57 Thobieb al-Asyhar, Fiqh Progresif: Menjawab Tantangan Modernitas, cet. I (Jakarta, Fkku Press, 2003), h. 104 


\section{DAFTAR PUSTAKA}

\section{Al-qur'an/Tafsir}

Departemen Agama, al-Qur'an dan Terjemahnya, Surabaya: CV. Jaya Sakti,1997.

\section{Hadis/ Ilmu Hadis}

Bukha $>$ ri<, $S\{a h\{i<h\{$ Bukha $>r i<$, cet. III, 5 jilid, Beirut: Da $>\mathrm{r}$ al-Fikr, 1401/1981

Da $>$ ud, Abu $>$,Sunan Abi $<<D a>u d$, cet. I, 4 jilid, Beirut: Da $>\mathrm{r}$ al-Fikr, t.t

Hasby, ash-Shiddiqi, Pokok-Pokok Ilmu Dirayah Hadis, Jakarta: Bulan Bintang, 1981

Nawawi<, Ima>m an-, S\{ah\{i<h\{ Muslim bi Syarh\{i anNawawi<, cet. V, 18 jilid Beirut: Dar al-Fikr, t.t.

Suyu $>$ ti $<$, Jala $>1$ ad-Di<n as-, Sunan an-Nasa $>i$ bi Syarhi al$\mathrm{H}\{\mathrm{a}>$ fiz Jala $>1$ ad-Di<n as- $\mathrm{Suyu}>\mathrm{ti}<$, cet. I, 6 jilid, Beirut: Da>r al-Fikr, 1248/1930

Tirmi $<z i$, $<$ Abi ' $\mathrm{I}<\mathrm{sa}>\operatorname{Muh}\{$ ammad bin Sawrah at- Sunan atTirmi<zi, 5 jilid, Beirut: Da>r al-Fikr, 1408/1988

\section{Buku}

Adhim, Mohammad Fauzil, Kupinang Engkau Dengan Hamdallah, cet. VII, Yogyakarta: Mitra Pustaka, 1999

Arief, Abd. Salam, Pembaharuan Pemikiran Islam Antara Fakta dan Realita, cet. I, Yogyakarta: Lesfi, 2003

Asyhar Thobieb al-, Fiqh Progresif: Menjawab Tantangan Modernitas, cet. I, Jakarta, Fkku Press, 2003

Halim, Abdul,"Ijtihad Kontemporer: Kajian Terhadap Beberapa Aspek Hukum Keluarga Islam Indonesia," dalam Ainurrofiq (ed.), Mazhab Jogja: Menggagas Paradigam Ushul Figh Kontemporer, cet. I, Yogyakarta: Fakults Syari'ah IAIN Sunan Kalijaga + ar-Ruzz Press, 2002

Haroen, Nasrun, Ushul Fiqh I, cet. I, Jakarta: Logos Publishing House, 1996 
Hosen, Ibrahim, Fiqh Perbandingan Masalah Pernikahan, cet. I, Jakarta: Pustaka Firdaus, 2003

Ismail, Nurjanah, Perempuan dalam Pasungan: Bias Laki-Laki dalam Penafsiran, cet I , Yogyakarta: LKiS, 2003

Ibn Rusyd, Bida>yah al-Mujtahid Wa Niha>yah Al-Muqtas\{id (Analisa Fiqh Para Mujtahid), alih bahasa Imam Ghazali Said dan Achmad Zaidun, cet. II, 3 jilid, Jakarta: Pustaka Amani, 2002

Ikhsanuddin K.M., dkk. (ed.), Panduan Pengajaran Fiqh Perempuan di Pesantren ,Yogykarta: Yayasan Kesejahteraan Fatayat, t.t.

Jawziyyah, Ibn Qayyim al-, Za>d Al-Ma'a $>d$, 4 jilid, Mesir: Mus $\{\mathrm{t}\{\mathrm{a}>\mathrm{fa}>$ al-Ba $>\mathrm{bi}<$ al-H $\{$ alibi $<$ wa Awla $>$ dih, 1390/ 1970

----------, I'lam al-muwaqqi $i<n, 4$ jilid, Beirut: Da>r al-Kutub al-'Ilmiyyah, 1991

Jazi>ri>, 'Abdul ar-Rah\{ma>n al-, al-Fiqh 'ala> al-Maza>hib al-Arba'ah, 4 jilid, Beirut: Da>r al-Afka>r, t.t.

Mas'udi, Husein, Fiqh Perempuan Refleksi Kiyai Atas Wacana Agama dan Gender, Yogykarta: LKiS, 2001

Mas'udi, Masdar F.,"Meletakkan Maslahat Sebagai Kerangka Acuan Syari'ah", Ulumul Qur'an, Vol. 4: 3, 1995

Mughniyyah, Muhammad Jawad, Fiqih Lima Mazhab, alih bahasa Masykur A.B dkk., cet. V, Jakarta: PT.Lentera Basritama, 2000

Nasution, Khoiruddin, Islam: Tentang Relasi Suami Dan Istri (Hukum Perkawinan I), cet. I, Yogyakarta: Academia + Tazzafa, 2004

Nasution, Khoruddin,"Mensikapi Kitab-Kitab Fikih Konvensional dalam Menjamin Hak Wanita dalam Menentukan Pasangan", asy-Syir'ah, No. 8, 2001

Qaradhawi, Yusuf al-, Bagaimana Berinteraksi Dengan Peninggalan Ulama Salaf, alih bahasa Ahrul Tsani 
Fathurrahman dan Muhtadi Abdul Mun'im, cet. I, Jakarta: Pustaka al-Kautsar, 2003

--------- , Fatwa-Fatwa Kontemporer, alih bahasa As'ad Yasin Jakarta: Gema Insani Press

Rahman, Asymuni A., Reaktualisasi Hukum Islam Kearah Fiqh Indonesia, Yogyakarta: Forum Studi Hukum Islam Fakultas Syari'ah IAIN Sunan Kali Jaga, 1994

Rofiq, Ahmad, Hukum Islam di Indonesia, cet IV, Jakarta: PT. Raja Grafindo Persada, 2000

Shiddieqi, M. Hasby ash-, Filsafat Hukum Islam, cet. V, Jakarta: Bulan Bintang, 1993

-------- , Pengantar Fiqh Muamalah, cet. IVX, Semarang: PT. Pustaka Rizi Putra, 2001

Suhendi, Hendi, Fiqh Muamalah, cet. I, Jakarta: PT. Raja Grafindo Persada, 2002

Syaltut, Mahmud, Akidah dan Syari'at Islam,alih bahasa Fahruddin Hs. cet. III, Jakarta: Bumi Aksara, 1994

Syarifuddin, Amir, Ushul Fiqh II, cet. II, 2 jilid, Jakarta: Logos Wacana Ilmu, 2001

---------, Pembaharuan Pemikiran Dalam Hukum Islam Padang: Angkasa Raya, 1990.

Syubbag, Mahmud asy-, Tuntunan Keluarga Bahagia Menurut Islam, alih bahasa Bahruddin Fanani, cet. III, Bandung: Remaja Rosda Karya, 1994 